p53，c-erbB-2，PCNA，CD44，nm23の免疫組織染色所見からみた 大腸癌異時性肝転移高危険群の検索について

\begin{tabular}{|c|c|c|c|c|c|c|c|}
\hline \multicolumn{8}{|c|}{ 岐阜大学医学部第 2 外科 } \\
\hline 北村 & 文近 & 佐治 & 重豊 & 深田 & 代造 & 宮 & 喜一 \\
\hline 国枝 & 克行 & 杉山 & 保幸 & 鷹尾 & 博司 & 加藤 & 元久 \\
\hline
\end{tabular}

大腸癌術後異時性肝転移予測の可能性を検索する目的で, 治捴切除例で異時性肝転移 33 例 (転移群), 転移群と 1：2で度数マッチングさせた非転移66例（対照群）を対象とし，p53，c-erbB-2, PCNA， CD44，nm23を免疫組織化学的に検討した。転移群は対照群に比べ PCNA labeling index (LI) が有 意に高く, CD44陽性例, nm23陰性例が有意に多かったが, p53, c-erbB-2は雨群間に差を認めなかっ た. ROC 曲線による PCNA LI の異時性肝転移判別闇値は60であった。転移群の無再発期間は CD44 陽性例で有意に短縮し，nm23陰性例で短い傾向を示した。転移群の累積生存曲線は CD44陽性例で予 後不良となる傾向を示した。各因子の兔疫組織所見より算出した異時性肝転移確率は，1 項目では PCNA LI (0.23) が，2 項目では PCNA LI + nm23(0.62)が最も高かった. 免疫組織染色による PCNA LI, CD44, nm230検索は大腸癌治癒切除後の異時性肝転移高危険群の判別に有用であると推察され た.

Key words: metachronous liver metastasis of colorectal cancer, immunohistochemical stain, case control study, positive predictive value, receiver operating characteristic curve

はじめに

大腸癌は他の消化器癌に比べ比較的予後良好で, 血 行性転移, とくに肝転移に対しては転移巣に対する根 治的切除や化学療法が一定の成果を上げている。しか し，いまだ最大の予後規定因子であり，とくに治癒切 除後の異時性肝転移は, 初回手術時すでに存在する微 小転移巣の増大によるものと推察されており, 術後補 助療法の最大の標的臟器となる. それゆえ, 予後向上 のためには, この微小転移巣の存在, すなわち異時性 肝転移高危険群を的確に判別する必要がある。

ところで, 大腸癌の肝転移や予後の予测は従来, 組 織型, 深達度, リンパ節転移, 静脈侵襲などの病理組 織学的因子から行われてきたが1 3), 近年, 発癌におけ る遺伝子異常や, 癌転移における分子機構が解明され るにしたがい,これら癌関連遺伝子や癌関連抗原の転 移，予後への関与が検索されるようになった。このう ち免疫組織化学的手法を用いた検索では, 変異型 p53 タンパクの発現4や, proliferating cell nuclear

<1996年11月13日受理 >別刷請求先：北村 文近 $\overline{\mathrm{T}} 500$ 岐阜市司町 40 岐阜大学第 2 外科 antigen (PCNA) の陽性細胞比率 (labeling index, 以下 LI) が大腸癌の独立した予後因子と考えられてい る5).また, 転移関連因子として c-erbB-2, CD44, nm23 などが注目されているが，c-erbB-2は大腸癌のリンパ 節転移との有意な関連が報告され ${ }^{6)}$, 膜貫通型接着分 子であるCD44は大腸癌同時性肝転移との関連が報告 され7), 転移抑制遺伝子とされる nm23は，その発現減 弱と大腸癌の進行度や遠隔転移との関連が報告されて (るる8). しかし異時性肝転移の予測すなわち肝転移の 早期診断についてはいまだ十分な検索は少ない.

そこで, 免疫組織化学的方法を用いて，大腸癌原発 巣における p53, c-erbB-2, PCNA, CD44, nm23 と異 時性肝転移の関連を, 臨床病理学的因子をマッチング させたケースコントロールスタディにより解析し, 異 時性肝転移予測の可能性を検索した。

\section{対象と方法}

1. 対象症例の内訳と肝転移の診断法

1982年 1 月から1990年12月までに手術した進行大腸 癌症例のうち, 予後が判明している症例で組織学的根 治度 ${ }^{9}$ が A（si， ai を除く）の276例中, 術後に肝転移 が発見された33例を異時性肝転移（以下，転移）群と 
した。また, 術後 5 年以上を経過した無再発生存例中, 占居部位, 組織型, 壁深達度を転移群と $1: 2$ で度数 マッチングさせた66例を非肝転移対照（以下，対照） 群とした。なお, 対照群の抽出に際し適格症例が多数 存在した場合には無作為に抽出した.

再発, 転移の診断は, 術後 1 か月ごとの血清 carcinoembryonic antigen (以下, CEA) 值測定, 3 加月 ごとおよび血清 CEA 值上昇時の腹部超音波検查, 腹 部 computed tomography 検查, 胸部単純 $\mathrm{X}$ 線検査, 1 年ごとの胃, 十二指腸扝よび大腸内視鏡検査にて 行った.

肝転移の診断は, 12例は画像所見で, 21例は再開腹 時の転移巣切除による病理組織学的所見で判定した。 転移時期の判定は画像上確認可能となった時期とし た。なお，身体所見または画像所見で, 腹腔内腫瘤, 腹水貯留, 局所再発, 遠隔転移巣などの肝以外の転移, 再発が判明した症例, また血清 CEA 值が上昇したが 転移, 再発所見が確認できなかった症例は対象から除 外した. 既往歴および術後経過観察中に重複癌を認め た症例はなかった。

\section{2. 免疫組織染色の方法と判定法}

切除標本のホルマリン固定パラフィン包埋ブロック より $4 \mu \mathrm{m}$ の薄切連続切片を作製し脱パラフィン後, p53, c-erbB-2, CD44, nm23は avidine-biotinylated peroxidase complex (以下, ABC) 法で染色し, PCNA は enhanced polymer one-step staining (以下, EPOS) 法で染色した (Table 1).すなわち前者は0.3\% $\mathrm{H}_{2} \mathrm{O}_{2}$ 加メタノールにて30分間内因性ペルオキシダーゼを不 活化後, 1\%正常ウマ血清（p53，CD44）またはヤギ 血清 (c-erbB-2, nm23) を添加した 1 次抗体を $4{ }^{\circ} \mathrm{C} に$ て12時間 (p53, c-erbB-2, CD44)または室温にて30分 間 (nm23) 反応させ, ビオチン化 2 次抗体を 30 分間, $\mathrm{ABC}$ 試薬 (Vector, USA)を30分間反応させた. 次い で diaminobenzidine tetrahydrochloride で発色させ

Table 1 Primary antibodies used for immunohistochemical stain

\begin{tabular}{l|l|l|c}
\hline $\begin{array}{l}\text { Primary } \\
\text { antibody }\end{array}$ & \multicolumn{1}{|c|}{ Clone } & \multicolumn{1}{|c}{ Source } & $\begin{array}{l}\text { Working } \\
\text { dilution }\end{array}$ \\
\hline p53 & DO-7 & DAKO, Denmark & $1: 100$ \\
c-erbB-2 & polyclonal & DAKO, Denmark & $1: 200$ \\
PCNA & PC10 & DAKO, Denmark & - \\
CD44 & DF1485 & DAKO, Denmark & $1: 80$ \\
nm23 & polyclonal & $*$ & $1: 1,000$ \\
\hline
\end{tabular}

" : kindly provided by Prof. Tahara, Hiroshima Univ. hematoxylin で核染色後, 封入, 検鏡した. 後者は前 者同様に内因性ペルオキシダーゼを不活化し $1 \%$ 正常 ウマ血清にて30分間非特異的反応をブロック後, EPOS 抗体を室温にて60分間反応させ, 発色, 核染色 後, 封入，検鏡した。なお陽性対照はいずれも既知の 陽性標本を用い10)，陰性対照は $\mathrm{ABC}$ 法で牥各 1 次抗 体を, EPOS 法では EPOS 抗体を除いて染色した標本 を用いた。

判定は, p53は癌細胞の核が集簇的に染色されたも のを陽性とし，少数の核が散在的に染色されたものは 陰性とした. c-erbB-2と CD44は細胞膜が染色された ものを陽性とし, $\mathrm{nm} 23$ は細胞質が正常粘膜細胞以上に 濃染されたものを陽性, 正常粘膜細胞より染色性の低 いものを陰性とした. PCNA は核が染色されたものを 陽性とし, 腫瘍最深部に扔ける癌細胞500個中の陽性細 胞数を PCNA LI とし, 百分率で表示した. な㧍, 判 定はいずれも光学顕微鏡高倍率視野 $(\times 400)$ で行った.

PCNA LI は receiver operating characteristic (ROC) 曲線 ${ }^{11}$ を描記し, 左上隅に最も近い PCNA LI 値を cut-off 值とした。

\section{3. 陽性予測值の算定法と統計学的検討法}

両群の各因子の検査陽性率より, 単独および組み合 わせによる検査陽性予測值 ${ }^{12)}$ すなわち検查陽性時の異 時性肝転移確率を算定した。検查前確率は本研究期間 における異時性肝転移発生率とした。

数值は mean \pm standard deviation (SD) で示し, 検定は Student's t-test を用いた。背景因子の差の検定 には Mann-Whitney's U-test を用い, 出現率の差の検 定には chi-square test を, 少数例の検討では Fisher's exact probability methodを用いた。累積生存率は Kaplan-Meier 法にて算出し, logrank testを用いた。 いずれも $\mathrm{p}<0.05$ 有意とした。

また, 臨床病理学的用語は大腸癌取扱い規約 ${ }^{9} に$ 従った。

1. 背景因子の検討

転移群の占居部位は結腸が17例，直腸が16例，組織 型は高分化型が16例，中分化型が15例，低分化型が 2 例，壁深達度は $\mathrm{mp}, \mathrm{ss} ・ \mathrm{a}_{1}, \mathrm{se} \cdot \mathrm{a}_{2}$ がそれぞれ 6 例， 21例, 6 例で, いずれも対照群は $1 ： 2$ で度数マッチ ングさせた。非マッチング背景因子では, 転移群は対 照群に比べ, 組織学的 stage III b, リンパ節転移 $\mathrm{n}_{2}$ 以 上の症例が若干多くみられたが，これらを含め，いず れも両群間に有意差を認めなかった（Table 2). 
Table 2 Patients' characteristics of the group of metachronous liver matastasis and control, matched for tumor location, depth of invasion, and histological typing

\begin{tabular}{|c|c|c|c|}
\hline & $\begin{array}{l}\text { Metachronous } \\
\quad(n=33)\end{array}$ & $\begin{array}{l}\text { Control } \\
(n=66)\end{array}$ & P-value \\
\hline \multicolumn{4}{|c|}{ histological stage } \\
\hline I & 1 & 6 & \multirow{4}{*}{0.1770} \\
\hline II & 6 & 14 & \\
\hline III a & 12 & 26 & \\
\hline III b & 14 & 20 & \\
\hline \multicolumn{4}{|c|}{ lymph node metastasis } \\
\hline$n_{\|}$ & 7 & 20 & \multirow{4}{*}{0.1105} \\
\hline$n_{1}$ & 12 & 26 & \\
\hline $\mathrm{n}_{1}$ & 9 & 19 & \\
\hline$n_{4}$ & 5 & 1 & \\
\hline \multicolumn{4}{|c|}{ lymphatic invasion } \\
\hline $1 y_{0}$ & 5 & 13 & \multirow{4}{*}{0.8200} \\
\hline $\mid y_{1}$ & 13 & 21 & \\
\hline $\mathrm{Iy}_{2}$ & 7 & 19 & \\
\hline $\mathrm{Iy}_{4}$ & 8 & 13 & \\
\hline \multicolumn{4}{|c|}{ venous invasion } \\
\hline$v_{i 4}$ & 18 & 42 & \multirow{4}{*}{0.5137} \\
\hline $\mathrm{v}_{\mathrm{i}}$ & 12 & 15 & \\
\hline $\mathrm{v}_{4}$ & 1 & 9 & \\
\hline$v_{3}$ & 2 & 0 & \\
\hline
\end{tabular}

\section{2. 免疫組織染色性の検索結果}

両群間の比較で，PCNA LI 值は転移群が61.5士 10.7 と対照群の54.9土11.5に比べ有意に高值を（p= 0.0070)，CD44陽性率は転移群が $66.7 \%$ と対照群の $33.3 \%$ に比べ有意に高值を $(\mathrm{p}=0.0033)$ 示し, $\mathrm{nm} 23$ 陽性率は転移群が $45.5 \%$ と対照群の $71.2 \%$ に比べ有意 に低值を示した $(\mathrm{p}=0.0227)$ 。一方，p53，c-erbB-2は 両群間で有意差はみられなかった（Table 3).

\section{PCNA LI cut-off 值の検索結果}

ROC 曲線の左上隅に最も近いLI 值は60であった (Fig. 1).この cut-off 值を用いた PCNA LI 高值例の 頻度は転移群で有意に高く $(p=0.0018)$, 以下の検討 では PCNA LIミ60を高値群, く60を低值群とした (Table 3).

\section{4. 病理組織学的因子との関連}

転移群と対照群を合わせた全例での組織学的病期と の関連では，nm23陰性群では病期が有意に高く（p= 0.0209), PCNA LI 高值群では病期が高くなる傾向を

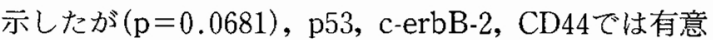
の関連はみられなかった。また，リンパ節転移程度と
Fig. 1 Receiver operating characteristic (ROC) curve of PCNA LI as predictor for metachronous liver metastases on curatively resected colorectal cancer

* : the closest plot to the upper left-hand corner of the frame

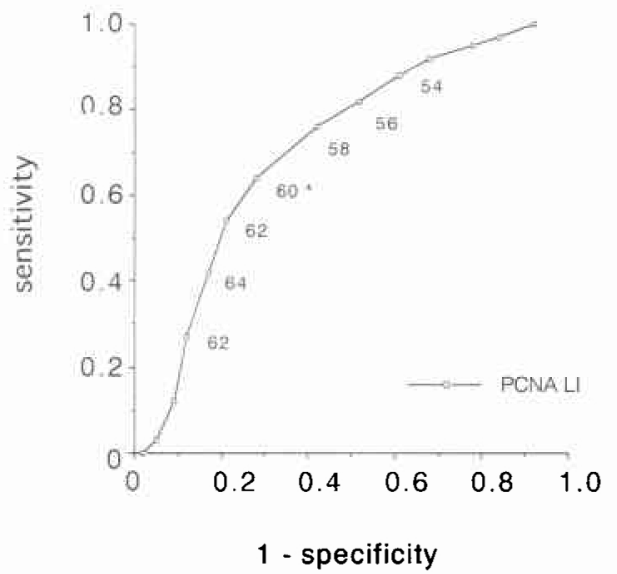

Table 3 A comparison on positive rates of p53, c-erbB2. CD44, and nm23, and PCNA labeling index evaluated by immunohistochemical stain between matachronous group and controls

\begin{tabular}{l|c|c|c}
\hline & $\begin{array}{c}\text { Metachronous } \\
\%(n=33)\end{array}$ & $\begin{array}{c}\text { Control } \\
\%(n=66)\end{array}$ & P-value \\
\hline p53 & $57.6(19)$ & $47.0(31)$ & 0.4331 \\
c-erbB-2 & $45.5(15)$ & $28.8(19)$ & 0.1544 \\
PCNA LI & $61.5 \pm 10.7^{*}$ & $54.9 \pm 11.5^{*}$ & 0.0070 \\
CD44 & $66.7(22)$ & $33.3(22)$ & 0.0033 \\
nm23 & $45.5(15)$ & $71.2(47)$ & 0.0227 \\
\hline PCNA LI $\geqq 60$ & $63.6(21)$ & $28.8(19)$ & 0.0018 \\
\hline
\end{tabular}

(cases)

$*$ mean $\pm \mathrm{SD}$

の関連では, nm23陰性群でリンパ節転移程度が有意に 高く $(\mathrm{p}=0.0141)$, PCNA LI 高值群ではりンパ節程度 が高い傾向を示したが $(\mathrm{p}=0.0662)$ ，他はいずれも有 意の関連はみられなかった(Table 4)。なお，組織型， 壁深達度, リンパ管侵襲，静脈侵襲のいずれの項目と も免疫組織染色性との間には有意の関連はみられな かった。

5. 無再発期間, 累積生存率との関連

転移群に扔ける平均無再発期間 (disease free inter-

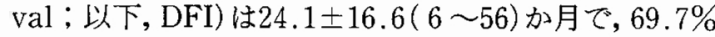
(23/33) の症例が24か月以内であった (Fig. 2)。CD44 
Table 4 Summary on positive cases of immunohistochemical stain according to histological stage and lymph node metastasis in overall cases

\begin{tabular}{|c|c|c|c|c|c|}
\hline & $\mathrm{p} 53$ & c-erbB-2 & $\mathrm{PCNA} \quad \mathrm{LI} \geqq 60$ & $\mathrm{CD} 44$ & $\mathrm{~nm} 23$ \\
\hline \multicolumn{6}{|c|}{ histological stage } \\
\hline I $\quad(n=7)$ & $4(3)$ & $3(4)$ & $2(5)$ & $4(3)$ & $6(1)$ \\
\hline II $\quad(n=20)$ & $11(9)$ & $7(13)$ & $5(15)$ & $9(11)$ & $14(6)$ \\
\hline III a $(n=38)$ & $18(20)$ & $11(27)$ & $16(22)$ & $13(25)$ & $26(12)$ \\
\hline III $b(n=34)$ & $17(17)$ & $13(21)$ & $17(17)$ & $18(16)$ & $16(18)$ \\
\hline P-value & 0.7004 & 0.8854 & 0.0681 & 0.6390 & 0.0209 \\
\hline \multicolumn{6}{|c|}{ lymph node metastasis } \\
\hline $\mathrm{n}_{0} \quad(\mathrm{n}=27)$ & $15(12)$ & $10(17)$ & $7(20)$ & $13(14)$ & $20(7)$ \\
\hline $\mathrm{n}_{1} \quad(\mathrm{n}=38)$ & $18(20)$ & $11(27)$ & $16(22)$ & $13(25)$ & $26(12)$ \\
\hline $\mathrm{n}_{2} \quad(\mathrm{n}=28)$ & $15(13)$ & $12(16)$ & $14(14)$ & $15(13)$ & $15(13)$ \\
\hline $\mathrm{n}_{3} \quad(\mathrm{n}=6)$ & $2(4)$ & $1(5)$ & $3(3)$ & $3(3)$ & $1(5)$ \\
\hline P-value & 0.6186 & 0.9876 & 0.0662 & 0.6112 & 0.0141 \\
\hline
\end{tabular}

(negative cases)

Fig. 2 Case distribution of disease free interval on metachronous cases

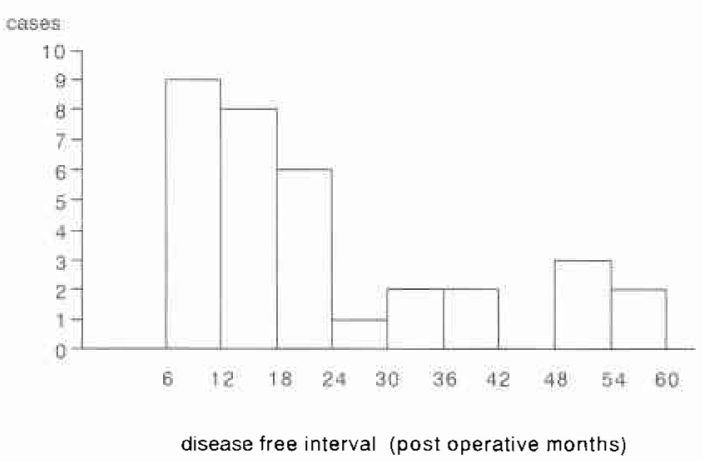

Table 5 A comparison of disease free intervals between immunohistochemical stain positive and negative cases on metachronous group

\begin{tabular}{l|c|c|c}
\hline \multirow{2}{*}{} & \multicolumn{3}{|c}{ Disease free interval (mean \pm SD, months) } \\
\cline { 2 - 4 } & Positive & Negative & P-value \\
\hline p53 & $21.1 \pm 14.4$ & $26.7 \pm 17.6$ & 0.3176 \\
c-erbB-2 & $25.5 \pm 16.8$ & $21.8 \pm 15.3$ & 0.5137 \\
PCNA LI* & $23.2 \pm 16.9$ & $23.8 \pm 14.4$ & 0.9192 \\
CD44 & $18.7 \pm 10.9$ & $32.9 \pm 20.1$ & 0.0128 \\
nm23 & $27.9 \pm 18.1$ & $18.1 \pm 10.9$ & 0.0737 \\
\hline
\end{tabular}

* : positive ; $\mathrm{PCNA} L \mathrm{LI} \geqq 60$, negative ; $\mathrm{PCNA} \mathrm{LI}<60$

陽性群は DFI が有意に短縮し $(\mathrm{p}=0.0128), \mathrm{nm} 23$ 陰性 群では DFI が短くなる傾向を示した $(\mathrm{p}=0.0737)$.し かし, p53, c-erbB-2, PCNA LI はいずれも DFI との 間に有意の関連はみられなかった（Table 5)。

累積生存率との関連では, CD44陽性例は陰性例に比
Fig. 3 A comparison of cumulative survival curves between CD44-positive and negative cases of metachronous group

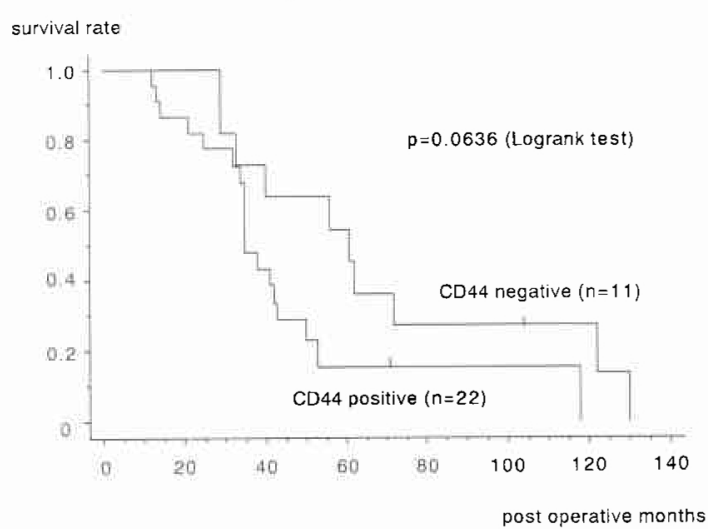

べ予後不良となる傾向 $(\mathrm{p}=0.0636)$ を示したが (Fig. 3), p53 ( $\mathrm{p}=0.7065)$, c-erbB-2 $(\mathrm{p}=0.6170)$, PCNA LI $(p=0.5574), n m 23(p=0.3730)$ はいずれも有意 の関連はみられなかった。

6. 検査陽性予測値の算定

免疫組織染色率で有意差が認められた PCNA LI, CD44, nm23を用い, PCNA LI 高值, CD44陽性, nm23 陰性を検査陽性とした場合の検査陽性予測值を算定し た. 1 項目では, PCNA LI が0.23と最高で, 以下, CD44, nm23の順であった。 2 項目では PCNA LI と $\mathrm{nm} 23$ の組み合わせが 0.62 と最高值を示した, 3 項目で は0.62 と 2 項目の最高値と同値であった（Table 6). な扔, 背景因子でリンパ節転移程度に若干の差がみ られたので, $\mathrm{n}_{0-1}$ 症例について検討すると, 症例数は少 
Table 6 A comparison of immunohistochemical stain positive predictive values for metachronous liver metastasis among PCNA LI $\geqq 60$, positive CD44 and negative nm23

\begin{tabular}{l|r|r|l|l|l|l}
\hline \multirow{2}{*}{} & \multicolumn{2}{|c|}{ Groups } & \multirow{2}{*}{ P-value } & Sn & Sp & PV-pos \\
\cline { 2 - 3 } & $\mathrm{M}$ & $\mathrm{C}$ & & & & \\
\hline PCNA LI $\geqq 60$ & 21 & 19 & 0.0018 & 0.64 & 0.71 & 0.23 \\
CD44 (+) & 22 & 22 & 0.0033 & 0.67 & 0.67 & 0.22 \\
nm23 (-) & 18 & 19 & 0.0228 & 0.55 & 0.71 & 0.21 \\
\hline and & & & & & & \\
PCNA, nm23 & 12 & 2 & 0.0001 & 0.36 & 0.97 & 0.62 \\
CD44, nm23 & 12 & 4 & 0.0003 & 0.36 & 0.94 & 0.45 \\
PCNA, CD44 & 15 & 9 & 0.0008 & 0.45 & 0.86 & 0.30 \\
PCNA, CD44. nm23 & 8 & 1 & 0.0006 & 0.24 & 0.98 & 0.62 \\
\hline
\end{tabular}

incidence $33 / 276=0.12$

$\mathrm{M}$ : metachronous, $\mathrm{C}$ : control, $\mathrm{Sn}$ : sensitivity, $\mathrm{Sp}$ : specificity, PV-pos : positive predictive value

Table 7 A comparison of immunohistochemical stain positive predictive values for metachronous liver metastasis among PCNA LI $\geqq 60$, positive CD44 and negative $\mathrm{nm} 23$ on $\mathrm{n}_{0-1}$ cases

\begin{tabular}{l|r|r|r|r|r|r}
\hline & \multicolumn{2}{|c|}{ Groups } & P-value & Sn & Sp & PV-pos \\
\cline { 2 - 4 } & M & C & & & & \\
\hline nm23 (-) & 10 & 9 & 0.0180 & 0.53 & 0.80 & 0.21 \\
CD44 (+) & 13 & 13 & 0.0068 & 0.68 & 0.72 & 0.19 \\
PCNA LI $\geqq 60$ & 10 & 12 & 0.0769 & 0.53 & 0.74 & 0.17 \\
\hline and & & & & & & \\
CD44, nm23 & 7 & 2 & 0.0017 & 0.37 & 0.96 & 0.48 \\
PCNA, nm23 & 6 & 2 & 0.0060 & 0.32 & 0.96 & 0.44 \\
PCNA, CD44 & 9 & 7 & 0.0091 & 0.47 & 0.85 & 0.24 \\
PCNA, CD44, nm23 & 5 & 0 & 0.0014 & 0.26 & 1.00 & 1.00 \\
\hline
\end{tabular}

incidence $19 / 206=0.09$

$\mathrm{M}$ : metachronous, C : control, $\mathrm{Sn}$ : sensitivity, $\mathrm{Sp}$ : specificity, PV-pos : positive predictive value

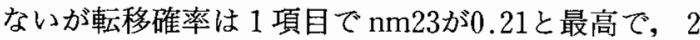
項目では CD 44 と nm23の組み合わせが 0.48 と最も高 く,3 項目では, 対照群に該当症例がなく転移確率 1.00 となった（Table 7).

\section{考 察}

大腸癌治癒切除後の異時性肝転移は, 初回手術時す でに存在した微小転移巣の増大によるもの, 転移陽性 遺残リンパ節からの 2 次的転移, 術中腫崵揉み出し操 作に起因した癌細胞の門脈内散布による可能性などが 推察されるが, 後 2 者は, 教室の樫塚ら ${ }^{13}$ による CEA slope analysisによる検討および術中腫場揉み出し操 作の実験的検討により，その可能性は予想以上に少な いと報告されている。したがって異時性肝転移は大部
分が潜在的同時性肝転移と推察され，著者らは占居部 位, 組織型，壁深達度を度数マッチングさせた対照群 との比較において, 原発巣の免疫組織化学的検索から 異時性肝転移予測の可能性を検討した。

本研究では，マッチングさせなかった静脈侵襲程度 は，転移群と対照群の間で有意差はみられなかった。 静脈侵襲と同時性肝転移との関連を示唆する報告は多 (が3)14), 異時性肝転移との関連を検討した報告は少 ない. 教室の樫塚らは325例の検討で, 同時性と異時性 では静脈侵襲に有意差が認められたが，異時性肝転移 群と非転移群との間に差は認められなかったと報告し ている ${ }^{13)}$. 本研究は大腸癌取扱い規約に従い, 腫瘍中心 部最大割面での Hematoxylin-Eosin 染色所見である 
が，弾性線維染色を用いた腫瘍全割連続切片での検討 においても，mp 以深部に静脈侵襲を認めた症例では 転移との関連が認められなかったとする報告や2)，静 脈侵襲率は異時性肝転移例で有意に高かったが大腸癌 取扱い規約に基づく静脈侵襲程度との関連は認められ なかったとする報告がなされて抢り ${ }^{15)}$, 著者らの結果 と一致する.したがって大腸癌取扱い規約に基づく静 脈侵襲は異時性肝転移予測の指標とはなりがたいと考 えている。

大腸癌異時性肝転移予測の指標として今回 p53, cerbB-2, PCNA LI, CD44, nm23の 5 項目について検 討したところ, 対照群との間に有意差がみられたのは PCNA LI, CD44, nm23の 3 項目であった. 以下に各 因子の特徴と異時性肝転移に扔ける検索意義を考察す る.

PCNA は $\mathrm{G}_{1}$ 後期から $\mathrm{S}$ 期前半に存在する細胞增殖 期関連核タンパクで ${ }^{16)}$, 大腸癌で予後との関連が報告 されている $61.5 \pm 10.7$ と対照群の $54.9 \pm 11.5$ に比べ有意の高值を 示した。諸家の報告扔よび本研究から，LI 值が高いほ ど悪性度が高いと推察されるが, その cut-off 值は平均 值や中間值を用いた報告が多い。著者らは各 LI 值に おける異時性肝転移の感度と特異度から ROC 曲線を 用いて解析し cut-off 値を 60 と判定した. その結果, 60 以上の高值例は有意に転移群に多く, 組織学的病期や リンパ節転移程度も高い傾向を示した。また，この LI 値60は大腸癌の Dukes 分類や DNA ploidy を有意に 判別する cut-off 值と同一值で ${ }^{17)}$, 著者らの正当性が支 持されたものと考えている。なお，PCNAの抗原性は 固定方法により変化するため, bromodeoxy uridine による細胞増殖活性と最も相関するエタノール 1 日固 定法が推奨されている ${ }^{18)}$. 著者らは大腸癌取扱い規約 に基づき $20 \%$ ホルマリンで 3 日間固定した標本を用い たが，PC10抗体を用いたEPOS 法では安定した染色 性を示し, LI 値も諸家の報告と比べ著差はみられず, 進行大腸癌症例ではホルマリン固定で十分検討しうる と考えている。

本研究では転移群の CD 44 陽性率は $66.7 \%$ と対照群 の $33.3 \%$ に比べ有意に高値を示し，転移群に扔ける CD44陽性例の DFI は有意に短縮し, 予後不良であっ た.リンパ節転移や組織学的病期との間に有意の関連 はみられなかったが, Ichikawa も CD44陽性例は同時 性肝転移例や術後再発例が有意に多かったが, リンパ 節転移との間には関連がなかったと報告しており7，
著者らの結果と一致する.CD44はstandard form $(\mathrm{CD} 44 \mathrm{~s})$ と variant isoform $(\mathrm{CD} 44 \mathrm{v})$ が存在し, CD44 $\mathrm{v}$ の発現は癌の進展と関連すると報告されている ${ }^{19)}$. 著者らは CD $44 \mathrm{~s}$ のみ検索したが, CD $44 \mathrm{v}$ との同時 発現例では細胞外に高分子複合体を形成し抗原性が高 まると報告されて抢り ${ }^{20)}$ ，また挿入配列の部位によっ ては CD44v 自体が CD44s 抗体に反応する可能性も推 察される.したがって CD44s の免疫組織化学的発現例 にCD $44 \mathrm{v}$ の発現例も含まれる可能性が十分考えられ, CD44s の免疫組織化学的検討は有用であると考えて いる.

nm23は転移能の低い細胞株で高発現し, 高転移株に 遺伝子導入すると転移能が低下することから癌転移抑 制遺伝子と理解されている ${ }^{8)}$. 著者らは正常粘膜に比 べ低染色性を示す場合を陰性と判断したが，異時性肝 転移例では有意の染色性低下を示し, nm23陰性例で組 織学的病期やリンパ節転移率が有意に高く, DFI も短 縮する傾向がみられた。この結果は, nm23が血行性転 移やリンパ節転移に対しても抑制遺伝子として関与す る可能性を示唆しているが, 腺腫から進行癌まで一貫 して発現が認められたとする報告もあり ${ }^{21)}$, 必ずしも 癌に抑制的に作用するわけではなく, 進展程度により 作用機序が異なる可能性が推察される。

ところで, p53と c-erbB-2は今回の検討では異時性 肝転移の予測指標とはならず, 組織学的病期, リンパ 節転移, DFI, あるいは転移群における予後との間にも 有意の関連はみられなかった. p53と癌の予後との関 連は, 症例数が多いほど有意とする報告の比率が高 〈"), 予後因子としては確立している. 一方, 肝転移と の関連は著者らの結果同様に, 認められないとする報 告が多く ${ }^{2223)}$, 有意関連を主張する報告でも異時性肝 転移との関連は確認されていない24).したがって, p53 の免疫組織化学的発現は癌の進展には関与するが, 異 時性肝転移予測指標としては有用性は低いと考えてい る.

c-erbB-2も肝転移との有意な関連を認めないとする 報告 ${ }^{25)}$ がある一方, 異時性肝転移例では非転移例に比 べ有意に陽性率が高いとする報告がみられる ${ }^{26)}$. 後者 は早期癌を含み, 非転移例での陽性率が $4.4 \%$ と自験例 および他の報告例と比べ著しく低く, 背景因子の差が 関与している可能性が推察される.

一般にケースコントロールスタディでは, 群間に有 意差が存在することが比較項目の有用性を示す．本研 究では PCNA LI, CD44, nm23が対照群に比べ有意差 
を示し，有用な検查項目と推察されるが，有意差が肺 転移の可能性をどの程度予測できるのかは不明で, 検 査結果の臨床的評価には至らない。一方, 検查法の有 用性を判断する指標として感度, 特異度が挙げられる が，これは疾病（正常）における検査陽性（陰性）比 率を示すため，検查陽性時における判断基準としては 妥当性が少ない。これに対し, 検査陽性予測值は感度, 特異度, 検查前確率を用いて検査陽性時の疾病確率を 求めるもので ${ }^{22)}$, 著者らは各検查陽性時の珙時性肝転 移確率として算出した。 その結果, 1 項目では PCNA LIが最も優れており，2項目ともに陽性の場合, PCNA LI と nm23の組み合わせが異時性肝転移確率 0.62 と最も高値を示した。しかし， 3 項目では 2 項目 の最高値と同等で, 異時性肝転移予測の観点からはこ れら 3 項目すべてを検索する必要性は少ないと推察さ れた。一方, リンパ節転移程度の低い $\mathrm{n}_{0-1}$ 症例で同様 に検討すると, 1 項目では $\mathrm{nm} 23,2$ 項目では $\mathrm{CD} 44$ と nm23の組み合わせが最も高値を示し，全体例での結果 と異なった。この理由として, $\mathrm{n}_{0-1}$ 症例では PCNA LI の cut-off 値60におう恶度が低く, 群間差も有意でな いことから, $\mathrm{n}_{0-1}$ 症例では cut-off 值が異なる可能性が 推察されるが, 少数例の検討であり, 今後症例を蓄積 し多変量解析を用いた検討が必要であろう.

異時性肝転移群の DFI は 6 56か月間に分布し, 70\%の症例は24か月以内であった．したがって異時性 肝転移を念頭においた場合，少なくとも 2 年間は㛜重 な経過観察が必要である。一方, 異時性肝転移の治療 は, 腫湟量の少ないミクロレベルの時期すなわち術後 6 か月以内に行うのが効果的であると推察されるが, 異時性肝転移の予防的治療である経門脈的補助化学療 法は, randomized trial による検討において有効性に 議論を残している27)28).今回の検討では, 進行大腸癌治 癒切除例で異時性肝転移は $12 \%$ であった。この場合肝 転移に対する予防的治療は $88 \%$ が不適格例と推察され るので, 異時性肝転移高危険群の検索なしに予防的治 療を行えば不適格例が多数含まれることになり，先の 臨床治験で有効性が立証できなかった可能性がある。 また, 患者の quality of life の向上や医療経済学的見 地からも補助化学療法適応例の判定が求められてい る.これらの点において, 本研究で用いた免疫組織化 学的手法は手技的にも比較的簡単であり, 臨床応用可 能な検査法として有用性が高いと考えている.

稿を終えるにあたり，nm23抗体を御供与いただきました 広島大学医学部第 1 病理学教室田原榮一教授に深謝いたし
ます。

\section{文献}

1) Phillips RKS. Hittinger R. Blesovsky L et al : Large bowel cancer: surgical pathology and its relationship to survival. Br J Surg 71:604610, 1984

2）小西文雄：大腸癌の静脈浸潤に関する臨床病理学 的研究. 日消病会誌 $80: 1599-1609,1983$

3）小棚木均, 永沢 治,丹羽 誠ほか：数量化による 直腸癌の血行性転移と局所再発の予知の可能性. 日外会誌 89 ：1022-1027，1988

4) Dowell SP, Hall PA : The p53 tumour suppressor gene and tumour prognosis: Is there a relationship? J Pathol 177 : 221-224, 1995

5) Al-Sheneber IF, Shibata HR, Sampalis J et al : Prognostic significance of proliferating cell nuclear antigen expression in colorectal cancer. Cancer 71: 1954-1959, 1993

6) Saeki T, Salomon DS, Johnson GR et al : Associasion of epidermal growth factor-related peptides and type I receptor tyrosine kinase receptors with prognosis of human colorectal carcinomas. Jpn J Clin Oncol 25：240-249, 1995

7) Ichikawa W: Positive relationship between expression of CD44 and hepatic metastases in colorectal cancer. Pathobiology $62: 172-179$, 1994

8) Ayhan A, Yasui W, Yokozaki H et al: Reduced expression of nm23 protein is associated with advanced tumor stage and distant metastases in human colorectal carcinomas. Virchows Archiv B Cell Pathol 63 : 213-218, 1993

9）大腸癌研究会編. 大腸癌取扱い規約. 第 5 版. 金原 出版, 東京, 1994

10）白子隆志：各種免疫組織染色所見から評価した胃 癌の生物学的悪性度と予後に関寸る臨床的研究. 岐阜大医紀 43：469-479，1995

11) Knottnerus JA, Leffers $P$ : The influence of referral patterns on the characteristic of dignostic tests. J Clin Epidemiol 45 : 1143-1154, 1992

12) Vecchio TJ : Predictive value of a single diagnostic test in unselected populations. N Engl J Med 274: 1171-1173, 1966

13）樫塚登美男,佐治重豊, 宮 喜一ほ隹：大腸癌の異 時性肝転移に関寸る臨床的・実験的研究。貱㚖大医 紀 42:455-475, 1994

14) Tsuchiya A, Ando $Y$, Kikuchi $Y$ et al: Venous invasion as a prognostic factor in colorectal cancer. Surg Today 25:950-953, 1995

15）斉藤善広, 大内明夫, 後藤慎二ほか：静脈侵襲より みた大腸癌の血行性転移の特性. 日外会誌 93 ： 133-138, 1992

16) Bravo R, Frank R, Blundell PA et al : Cyclin/ PCNA is the auxiliary protein of DNA 
polymerase- $\delta$. Nature $326: 515-517,1987$

17) Lazaris AC, Davaris $P$, Nakopoulou $L$ et al: Correlation between immunohistochemical expression of proliferating cell nuclear antigen and flow cytometry parameters in colorectal neoplasia. Dis Colon Rectum $37: 1083-1089$, 1994

18）中野 浩, 生田目公夫, 仲吉昭夫ほか: Proliferating cell nuclear antigen (PCNA) 発現率による胃 知増殖活性の評価一その基礎的検討と臨床応用に ついて一. 日外会誌 $94: 580-591 ， 1993$

19) Wielenga VJM, Heider KH, Offerhaus GJA et al: Expression of CD44 variant proteins in human colorectal cancer is related to tumor progression. Cancer Res 53 : 4754-4756, 1993

20) Sleeman J, Moll J, Sherman L et al : The role of $\mathrm{CD} 44$ splice variants in human metastatic cancer. Cell adhesion and human disease. Wiley, Chichester, 1995, p142-156

21) Haut M, Steeg PS, Willson JKV et al: Induction of nm23 gene expression in human colonic neoplasms and equal expression in colon tumors of high and low metastatic potential. J Natl Cancer Inst 83:712-716, 1991

22) Yamaguchi A, Kurosaka Y, Fushida $S$ et al: Expression of $\mathrm{p} 53$ protein in colorectal cancer and its relationship to short-term prognosis. Cancer 70:2778-2784, 1992

23) Tomoda H, Kakeji $Y$ : Immunohistochemical analysis of p53 in colorectal cancer regarding clinicopathological correlation and prognostic significance. J Surg Oncol 58:125-128, 1995

24) Maruyama $K$, Tanaka $T$, Baba $S$ et al: p53 Accumulation in colorectal cancer with hepatic metastasis. Jpn J Cancer Res87 : 368-376, 1996

25）吉田典行, 金沢匡司, 水沼 廣ほか：Prostaglandins, c-erbB-2 および ploidy よりみた大腸癌肝転 移能の検討. 日消外会誌 $28: 673-678,1995$

26）大森一吉,内野純一,近藤征文ほか：大腸癌におけ る肝転移再発の予知一原発巣の病理組織学的所 見, c-erbB-2 蛋白発現および腫瘍核 DNA 量から の検討一、日消外会誌 $24: 2963-2969,1991$

27) Wereldsma JCJ, Bruggink EDM, Meijer WS et al: Adjuvant portal liver infusion in colorectal cancer with 5 -fluorouracil/heparin versus urokinase versus control. Cancer 65:425-432, 1990

28) The colorectal cancer chemotherapy study group of Japan : Five-year results of a randomized controlled trial of adjuvant chemotherapy for curatively resected colorectal carcinoma. Jpn J Clin Oncol 25:91-103, 1995

\title{
Predicion of Metachronous Liver Metastasis on Curatively Resected Colorectal Cancer by Immunohistochemical Staining of p53, c-erbB-2, PCNA, CD44, and nm23
}

\author{
Fumichika Kitamura, Shigetoyo Saji, Daizo Fukada, Kiichi Miya, Katsuyuki Kunieda, \\ Yasuyuki Sugiyama, Hiroshi Takao and Motohisa Katoh \\ Second Department of Surgery, Gifu University, School of Medicine
}

For the purpose of prediction of metachronous liver metastasis on curatively resected colorectal cancer, immunohistochemical expression of p53, c-erbB-2, CD44, nm23 and proliferating cell nuclear antigen labeling index (PCNA LI) was compared between 33 cases with metachronous liver metastasis (metachronous group) and 66 cases without liver metastasis (control group). Control group was frequency $(1: 2)$ matched with metachronous group for tumor location, depth of invasion, and histological typing. PCNA LI $(p=0.0070)$, CD44 positive late $(p=0.0033)$ and $n m 23$ negative late $(p=0.0227)$ of metachronous group were significantly higher than those of control group. Receiver operating characteristic (ROC) curve of PCNA LI indicated that the most compatible cut off value for liver metastasis was 60 . On the other hand, expression of p53 or c-erbB-2 showed no correlations with metastasis. On metachronous group, CD44 positive cases had significantly shorter disease free intervals (DFI) than negative cases ( $\mathrm{p}=$ $0.0128)$, and $n m 23$ negative cases had relatively shorter DFI than positive cases $(p=0.0737)$. Cumulative survival of CD44 positive cases was relatively lower $(p=0.0636)$ than that of negative cases. PCNA LI $\geqq$ 60 cases had the highest positive predictive value (PV-pos) on one test (0.23), and PCNA LI $\geqq 60$ and nm23 negative cases showed the highest one on two tests $(0.62)$ for liver metastasis. From above results it is suggested that immunohistochemical expression of CD44, nm23 and PCNA LI is useful for prediction of metachronous liver metastasis on curatively resected colorectal cancer.

Reprint requests: Fumichika Kitamura Second Department of Surgery, Gifu University, School of Medicine

40 Tsukasamachi, Gifu, 500 JAPAN 